\title{
Rethinking the interface between customary law and constitutionalism in sub-Saharan Africa
}

\author{
Anthony C Diala \\ LLB, PGDip, LLM, PhD \\ Senior Lecturer, University of the Western Cape, South Africa \\ Bethsheba Kangwa \\ $L L B, L L M$ \\ Doctoral Candidate, University of the Western Cape, South Africa
}

\begin{abstract}
SUMMARY
Constitutionalism in sub-Saharan Africa evolved from imperial European laws, which were imposed on Africa's agrarian political economies through legal transplants. Being historical continuities of imperial laws, state laws have a rule-obsessed approach to law, with its attendant justice delivery problems. Significantly, colonial legal transplant in Africa was accompanied by radical socioeconomic changes, whose persistent patterns of power, philosophy, and conduct are referred to as coloniality of power. The staggering extent to which coloniality affects the normative behaviours of Africans demands a reassessment of the status of indigenous African laws. This paper argues that most indigenous laws have transformed into customary laws through people's adaptations to legal, economic, religious, and globalisation-fuelled changes in intersecting social fields. It uses content analyses of 26 African Constitutions to assess the extent to which customary laws are accommodated. Suggesting that these Constitutions are future common laws, the article offers the foundational values of indigenous laws as building blocks of constitutionalism and legal integration in the continent.
\end{abstract}

\section{Introduction}

Constitutionalism is the idea that governmental authority is conferred and defined by the people through a fundamental law known as the Constitution. ${ }^{1}$ In the Global North, the Constitution reflects the customary laws of citizens, given that these laws had integrated with state laws through a long coexistence. However, this integrated legal system is not the case in sub-Saharan Africa, where mostly oral indigenous laws enjoyed normative monopoly just over a century ago. ${ }^{2}$

1 For discussion, see Chesterman "Imposed constitutions, imposed constitutionalism, and ownership" 2004 Connecticut Law Review 947; Holmes "Constitutions and constitutionalism" in Rosenfeld \& Sajó (eds) Oxford Handbook of Comparative Constitutional Law (2012) 189-214.

2 'Indigenous laws' are also referred to as 'people's law, folk law, adat law, traditional law' and 'autochthonous law.' See generally Allot \& Woodman (eds) People's Law and state law: The Bellagio papers (1985) 24. 
Here, European laws with industrial backgrounds forcefully displaced indigenous laws with agrarian backgrounds and entrenched themselves as the dominant legal order. Significantly, state laws abolished, modified, and rigidly regulated the application of indigenous laws. ${ }^{3}$ By so doing, it coercively changed the normative behaviours of Africans, thereby birthing what we regard today as customary law. However, the creation of customary law occurred in the context of dissonance between indigenous laws and state laws. Nowhere is this dissonance more evident than in African Constitutions, which, as prime products of imposed European laws, are the normative faces of state laws. We shall argue that the creation of customary law resulted from people's normative adaptations to the socioeconomic changes brought by colonial rule, of which the most influential is state laws. We shall demonstrate how these socioeconomic changes were backed by legislation, stamped by the courts, and enforced by law enforcement agents. Notably, all these processes of change were embedded in the phenomenon of legal transplant. ${ }^{4}$ Accordingly, to illumine our proposal for rethinking the interface of customary law and African Constitutions, we need to explain the significance of legal transplant for the interaction of laws in subSaharan Africa.

Legal transplant, defined here as the movement of rules and legal institutions from one state to another, may be classified into voluntary, coercive, and imposed types. It is imposed when the laws and judicial systems of a foreign state are forced on another state through conquest, colonialism, and some might add, neo-colonialism. ${ }^{5}$ Being a product of conquest, imposed legal transplant is unmindful of differences between the socio-political environments of the transplanting and recipient states. Accordingly, it had two consequences for African constitutionalism.

Firstly, it disregarded the free will of African peoples, who were on the receiving end of European laws and legal systems. Many early Constitutions in Africa were drafted by elites, who were either influenced by colonialists, or acquired political power through questionable ways that need not detain us here. ${ }^{6}$ Secondly, the invidious ways European laws displaced African legal orders resemble what Siems described as "malicious legal transplants."7 Rather than being an isolated event, colonial legal transplant in Africa was a comprehensive, self-replicating phenomenon, which was accompanied by radical socioeconomic changes that irrevocably affected the education, philosophy, religion, work, food, and dressing of Africans. In short, it created patterns of

3 Morse \& Woodman Indigenous law and the state (1988) 8.

$4 \quad$ Watson Legal transplants: An approach to comparative law (1993) 1.

5 Owen "The foreign imposition of domestic institutions" 2002 International organization 375-409.

6 Even South Africa's serenaded constitution had little input from the masses. For debate, see Sparks Tomorrow is another country: The inside story of South Africa's negotiated settlement (1995) 63.

7 Siems "Malicious legal transplants” 2018 Legal Studies 105. 
power, philosophy, and conduct, whose persistence has been aptly described as the coloniality of power. ${ }^{8}$

Given the staggering normative effects of coloniality and the historical continuities of state laws in Africa, the relevance and status of indigenous laws must be reassessed. So, to what extent do African Constitutions incorporate customary laws that emerge(d) from people's adaptations of indigenous laws to socioeconomic changes? In the context of constitutionalism with imperial roots, this article argues that coloniality characterises the legal systems of sub-Saharan Africa, specifically the emergence and forms of Constitutions. Colonial rule not only transformed indigenous laws into customary laws endowed with the rule-minded character of imperial law, it also contributed to the secondclass status of customary laws in African Constitutions. In furtherance of our argument, we used content analyses of 26 African Constitutions to assess the extent to which they accommodate customary laws. The main elements for assessing this accommodation are constitutional acknowledgements of the right to culture, communal life, equality of women and men, and matrimonial property. Others are provisions defining customary law, mandating courts to apply customary law, and affirming the socioeconomic changes that drive the dynamism of customary law. These elements stand at the intersection of colonial continuities and discontinuities in indigenous African laws. Also, they are useful for policy makers interested in the integration of state laws with customary laws.

Following this introduction, section II of this article explains how colonial rule created and reinvented most of what we regard today as customary laws. In so doing, we distinguish between indigenous laws and customary laws. While indigenous laws are remnants of the precolonial norms which people observe in their ancient forms, customary laws are adaptations of indigenous norms to socioeconomic changes. Given that colonial rule was coercive, the normative alterations it brought are imposed changes, thereby necessitating a differentiation between pre-colonial norms and post-colonial norms. Section III uses content analysis of African constitutions to explain how the constitutional statuses of indigenous laws display scant sensitivity to people's normative adaptations to socioeconomic changes. Thereafter, it demonstrates how the inferior legal status of indigenous laws impacts on justice delivery, especially for marginalised groups such as women. Section IV concludes with proposals.

8 Quijano "Coloniality of power and Eurocentrism in Latin America" 2000 International Sociology 215-232; Mignolo "Epistemic disobedience, independent thought and de-colonial freedom" 2009 Theory, Culture and Society 1-23. 


\section{Colonial creation of customary law}

Do contemporary African customary laws substantively reflect their precolonial forms? The answer is negative because law is a product of its historical environment. The reality of the African environment is that customary laws emerge(d) from people's adaptations of mostly oral indigenous laws to economic, legal, political, cultural, and religious changes in intersecting social fields. "In turn, these socioeconomic changes embody the confluence of European imperial interests with the preservationist and opportunistic interests of their subject chiefs, elders, and merchants. We refer to these individuals as African elites. As Roberts noted, "customary law is now widely regarded as a collaborative project shaped primarily by male colonial officials fearful of their fragile control over newly colonized societies and by elderly African males equally fearful about the challenges to their authority." 10 We will discuss the interests embedded in this collaborative project in turn.

\section{Imperial interests}

The interests of European colonisers in Africa are well documented. ${ }^{11}$ The most important is economic exploitation, which was achieved with the aid of territorial, political, normative, and even religious subjugation of African communities. ${ }^{12}$ Being intrinsically exploitative, colonial rule was implemented with rule-obsessed or legal positivist law, referred to here as imperial law. ${ }^{13}$ To understand the significance of imperial law, one needs to appreciate the modern roots of legal transplant.

Taking classical antiquity as a historical reference point, the most significant use of legal transplants in modern times may be attributed to the Roman Empire. ${ }^{14}$ As the most enduring empire in recorded history, the Romans imposed their laws on Northern Europe, Scandinavia, the

9 Diala "The concept of living customary law: A critique" $2017 \mathrm{~J}$ of Legal Pluralism and Unofficial Law 143-165.

10 Roberts "Colonialism and Customary Law in Africa: A Response to Leslye Obiora" 1993 Legal Studies Forum 253.

11 See, for example, Rodney How Europe underdeveloped Africa (1971); Njoh "The impact of colonial heritage on development in Sub-Saharan Africa" 2000 Social Indicators Research 161-178.

12 For an illuminating discussion of colonialism and religion in Africa, see Nunn "Religious conversion in colonial Africa" 2010 American Economic Review 147-52.

13 Legal positivism perceives law from the lens of verifiable social facts rather than morality or values. See Austin (1832) The province of jurisprudence determined (Rumble ed) (1995) 157.

14 In simple terms, classical antiquity denotes the epoch between the 8th century $\mathrm{BC}$ and the 6th century $\mathrm{AD}$, a period in which the Greco-Roman world (great civilizations of ancient Greece and ancient Rome) flourished around the Mediterranean Sea. 
Middle East, and North Africa, ${ }^{15}$ using the rule of legal change. ${ }^{16}$ This rule was founded on a positivist view of law - that is the idea of law as a command enforceable by force if necessary. As we know, this idea of law ignores law's "interactional" character, as well as its "power differentials." 17

Previously, moral values and communal needs had dominated ideas of laws in many of the tribes that came under Roman rule. Rome's imperial law made it easy for their generals to form and administer nation-states under centralised leaderships founded on cooperative governance between the conquered tribes and their Roman overlords. Moreover, it was the most effective way to ensure that the conquered peoples accepted the new Sheriff in town. Unfortunately, rather than normative change to emerge from below in response to people's adaptation to social changes, imperial law imposed change from above. By divorcing values (morality) from law and giving normative change a rule-obsessed character, imperial law arguably sowed the seeds for the destructive series of battles known as the Thirty Years War. These battles eventually birthed the Peace of Westphalia, ${ }^{18}$ which, as widely acknowledged, laid the foundations of state sovereignty, from which modern Western legal systems emerged. As Halpérin stated, normative behaviour all over Europe embraced the disturbing reality "of a new statute abrogating an old one" without the need for change to initiate from people subject to the new statute. ${ }^{19}$ Like a bad habit, this disturbing reality accompanied British, French, Belgian, Portuguese, Italian, and German conquests of Africa. It coloured their understanding of African indigenous laws, as presented to them by the natives.

Significantly, imperial law was accompanied by revolutionary changes such as wage labour, urbanisation, new religion, education, food, dressing, forms of property, and individualistic worldview. These changes radically altered the social organisation of African communities, with considerable impact on their indigenous laws. One of the most known impacts of these alterations is the diminished status of women. ${ }^{20}$ Another is state ownership of all land. ${ }^{21}$ As agriculture became commercialised, women became excluded from production policies, lost

15 For an overview of the Roman Empire, see Sherman Roman law in the modern world volume 2 (1922).

16 Benton \& Straumann "Acquiring empire by law: From Roman doctrine to early modern European practice" 2010 Law and History Review 1-38.

17 Kidder "Toward an integrated theory of imposed law" In Burman \& HarrellBond (eds) The Imposition of Law (1979) 291.

18 Bring "The Westphalian Peace Tradition in International Law: From Jus ad Bellum to Jus contra Bellum" 2000 International Law Studies 58.

19 Halpérin "The concept of law: A Western transplant?" 2009 Theoretical Inquiries in Law 333.

20 Korieh "The invisible farmer? Women, gender, and colonial agricultural policy in the Igbo region of Nigeria, c. 1913-1954" 2001 African Economic History 124.

21 Meek "A note on Crown land in the colonies" $1946 \mathrm{~J}$ of Comparative Legislation and International Law 87-91. 
arable lands to big firms, and ultimately, lost their economic power base. $^{22}$ In fact, in southern Africa, colonialists went as far as creating enforced settlements to which they confined Africans to land only deemed adequate for survival. By so doing, they rearranged means of livelihood, created new patterns of wealth, and invented social statuses, whose devastating effects on equality and wealth remain today.

Naturally, imperial law and its accompanying socioeconomic changes forced adjustments in normative behaviour. As shown below, these adjustments manifested in the manners Africans presented indigenous laws to Europeans.

\section{Native interests}

To understand how the kinship, tribal, economic, and political interests of Africans and European colonialists created customary laws, one must appreciate the nature of law. Generally, law is a product of human needs and aspirations, which emerges in a social context characterised by dynamism - that is an ability to respond to changing needs and situations. ${ }^{23}$ Indigenous laws are no different. Most of them emerged in agrarian settings in which families lived in close-knit units for purposes of defence and agricultural activities. ${ }^{24}$ In these communal settings, rights were mostly complementary and relational rather than absolute and hierarchical. The absence of absolutism in the exercise of rights was due to the overriding nature of family or communal interest in social relations. In a typical precolonial social setting, for instance, women played rights-related roles by cooking for the family, selling/bartering farm produce, and mediating in disputes. ${ }^{25}$ Indeed, we are persuaded by scholarly views that pre-colonial gender relations evolved in nonpatriarchal environments. ${ }^{26}$ Phenomena evidencing this argument include gender neutral names, attires, patterns of comportment, and even ritual ceremonies such as the Nrachi custom in southern Nigeria. ${ }^{27}$ The point here is that the close-knit, communal rights oriented nature of precolonial society is incompatible with the rule-based, hierarchical, and individualistic image with which European colonisers perceived African indigenous laws. For example, rights to land were rights of use, not alienation; ${ }^{28}$ the family head's powers over property inheritance were trustee-like, not dictatorial; ${ }^{29}$ and women exercised matrimonial

22 Boserup, Tan \& Toulmin Woman's role in economic development (2013) 36.

23 Obiora "Reconsidering African customary law" 1993 Legal Studies Forum 217-252.

24 Barton et al Law in radically different cultures (1983) 41-42.

25 See, for example, Nzegwu Family matters: feminist concepts in African philosophy of culture (2006) 188-190.

26 Sudarkasa "The status of women in indigenous African societies" 1986 Feminist Studies 101.

27 Nrachi custom helps a man raise a male child through his daughter by keeping her unmarried in his house.

28 Elias The nature of African customary law (1956) 159.

29 Mbatha "Reforming the customary law of succession" 2002 SAJHR 259286. 
property rights embedded within their influential roles in the family and larger community as priestesses, mothers, wives, sisters, aunts, mothersin-law, and grandmothers. Following colonial rule, however, the communal, dynamic, and process-oriented nature of indigenous laws changed.

\section{How indigenous laws changed}

It would be abnormal if the Africans who first encountered European colonisers were not perturbed over the motives of these strangers with different skin colours and seemingly magical objects like guns and mirrors. For purposes of protecting their families and properties, these Africans would have almost exclusively been men, not women. So, right from the start, the face of public governance was altered. As Chanock showed, Africans could have exploited the situation by presenting versions of customs that enhanced their social powers, or even manufactured powers they did not exercise in their communities. ${ }^{30}$ They would certainly have made mistakes in presenting their laws, since formidable language barriers existed between them and the new overlords. In most parts of Africa, these language barriers were overcome with the aid of natives who acted as interpreters, many of whom had poor mastery of English language after receiving crash courses in colonial schools. Other interpreters were former slaves from neighbouring communities, whose abilities to speak local dialects were poor.

Furthermore, many presentations of indigenous laws occurred in the context of disputes. Several factors such as interpreters' abilities, relationships with litigants, pecuniary interests, and political considerations influenced the presentation of customs. We can illustrate this argument with two typical examples involving inheritance and marital property rights. ${ }^{31}$ The parties here are an elderly family head who considered himself a defender of cultural and religious values, a court interpreter who recently converted to Christianity, and a European District Officer (Native Commissioner) who somehow managed to avoid asking rule-based questions even though he had no ethnographic research background: 32

"Inheritance dialogue

District Officer: Ask the chief to explain inheritance rights in his community.

Court interpreter: Master [District Officer] says you should tell him who inherits the property of a dead man in your community. He doesn't want long stories. Just tell us who inherits.

30 Chanock "Neither customary nor legal: African customary law in an era of family law reform" 1989 International Journal of Law and Family 72-88.

31 This dialogue is constructed from one of the authors' interviews of elders, traditional leaders, and customary court judges in southern Nigeria between 2014 and 2015, as well as "Icheoku", a 1980s Nigerian television comedy.

32 The identity of the community involved in the dispute is redacted. 
Family Head: In my community of XYZ, the land of fierce rivers, long valleys, and beautiful women, the oldest male son inherits the property of a deceased man. This is the custom of our people since time immemorial. Everyone in the village knows this. I don't know why Chungu (defendant) is using alien ideas to claim something that does not belong to him. Our custom is very clear on inheritance. In fact, the gods will punish anyone who denies it -

Court interpreter: [Cuts in mockingly] I told you Master doesn't want to hear long stories. In any case, there are no gods. There is only one God, the father of Jesus Christ our Saviour.

Family Head: I am sorry if I annoyed the white man. Please tell him only the eldest male son inherits the property of a dead man."

In the above dialogue involving the rule of male primogeniture, we draw attention to how the family head was given no opportunity to express African peoples" "love of intricate and eloquent rhetoric." 33 Being so restricted, he could not explain that the first son inherits family property because the close-knit structure of social life demanded an authority figure to protect the family's interests. Similarly, he did not explain the two-fold purpose of this rule: (1) to enable the first son to, literally, step into the shoes of the deceased as the family head. (2) to require the heir to administer the estate in a trustee-like manner - that is for the benefit of all who were dependent on the deceased person, especially wives, unmarried daughters, and younger male children. 34

We turn now to dialogue number two, which involves a family head anxious to assert a patriarchal view of indigenous laws and a court clerk/ interpreter, who, as a former slave, was almost despised in the jurisdiction in which he worked.

"Matrimonial property dialogue

District Officer: Ask the chief to explain matrimonial property rights in his community.

Court interpreter: Master says you should tell him whether women inherit property when they separate from their husbands.

Family Head: Women do not separate from their husbands in our community, so how can they inherit property?

Court interpreter: No, that is not what I asked! When a man sends a woman back to her father forever, does she have claims to marital property?

Family Head: [Contemptuously] If you know our people (community) well, you wouldn't ask that question. But I don't blame you because you are not from here -

Court interpreter: [Cuts in sharply] Never mind me! Just answer the question!

33 Fallers "Customary law in the new African states" 1962 Law and Contemporary Problems 607.

34 South African Law Commission Report on Harmonisation of the Common Law and the Indigenous Law 1999 (Project 90). 
Family Head: Such a thing is rare, as our fathers did not divorce their wives. Our women used to be well behaved until the white man's education started filling their ears with nonsense ... Anyway, if a man sends a woman with nasty character back to her husband, she has no right to the man's property because everything she owns belongs to the family in which she married. In fact, since the man is the head of the family, it means the woman belongs to the man.

Court interpreter: Master, the witness says a divorcing woman has no matrimonial property rights because she belongs to her husband." 35

In the above dialogue, the family head's degradation of the legal status of women is partly honest and partly obfuscating. Even though he was not asked specifically, nothing prevented him from acknowledging that women have limited marital property rights. He could have done this by explaining the social context of the family. He could have stated the rights of divorcing women to refund of bride wealth and collection of the marriage gifts they received from their own family, which were usually cooking utensils and items of adornment. ${ }^{36}$ In the agrarian settings in which matrimonial property rights emerged, these were the only conceivable properties women could own in a personal capacity, since other properties such as fishing, hunting, and farming tools were communal.

From the foregoing peek at how Africans presented indigenous laws to early European administrators, we see how the confluence of varying interests affected indigenous laws. These interests, we argue, coupled with the influence of socioeconomic forces, created contemporary African customary laws. This argument requires a distinction between indigenous laws and customary law, to which we now turn.

\section{Indigenous law versus customary law}

Ordinarily, customary law connotes the image of "custom" - that is an immemorial practice with historical continuity. However, the foregoing discussion has shown that "customary law in Africa is not what it used to be." 37 As we hinted in section I, indigenous laws are oral precolonial norms which people observe in their ancient forms, while customary laws are adaptations of precolonial norms to socioeconomic changes. This argument resonates with Starr and Collier's description of customary law as "the outcome of historical struggles between native elites and their colonial or postcolonial overlords." 38 Before theoretically

35 For similar account of matrimonial property, see Diala "A critique of the judicial attitude towards matrimonial property rights under customary law in Nigeria's southern states" 2018 AHRLJ 103-104.

36 Obi et al The customary law manual (1977) s 321 \& s 322.

37 Zenker \& Hoehne "Processing the paradox: When the state has to deal with customary law" in Zenker \& Hoehne (eds) The state and the paradox of customary law in Africa (2018) 1.

38 Starr \& Collier "Introduction: Dialogues in legal anthropology" in Starr \& Collier (eds) History and power in the study of law: New directions in legal anthropology (1989) 9. 
expanding this argument, we will illustrate it with two commonly recognisable examples.

Our first example is the male primogeniture rule. ${ }^{39}$ Supposing Sechaba, a wealthy businessman, died intestate, leaving three male children and two female children. If his entire estate is inherited by Mark, his eldest son, the applicable custom of inheritance here is classical male primogeniture. This is because the estate was divided in strict accordance with an ancient norm that emerged in response to the agrarian nature of precolonial society. However, supposing the estate is shared among all the children, even if inequitably. In this second scenario, a deviation from classical male primogeniture is evident. This deviation constitutes customary law, since it emerged from an adaptation of an indigenous norm to influences or changes such as acculturation, constitutional equality, new (religious/global) notions of fairness, family income patterns, urbanisation, and individualism. As evident in the popular Bhe case, ${ }^{40}$ urbanisation, and individualism are increasingly common - that is the reality that some modern heirs are selfish, live in cities far from ancestral homes, and lack adequate time to administer the estate of deceased persons for the benefit of their dependants.

Our second example of the distinction between indigenous laws and customary laws is custody rights over children. Prior to colonial rule, women had limited custody rights over children who were past weaning age. ${ }^{41}$ This is largely because most African societies are patrilineal. However, in the communal social settings in which this custom emerged, divorce was rare, since marriage was a near-indissoluble alliance between families, one in whose success the entire community invested their peace and reconciliation energies. ${ }^{42}$ On the rare occasions divorce occurred, it was difficult for the interests of children to be negatively affected because the close-knit nature of the (extended) family acted as a safety check against children's maltreatment. This safety check resonates with the best interest of the child principle found in state laws. Accordingly, when the rate of divorce spiked and began causing hardships to women and children, it was easy for the indigenous law of child custody to adapt. Recognising the realities of urbanisation, acculturation, equality rights, independent income, and similar socioeconomic elements, traditional communities began to accord divorcing women custody rights over their children. ${ }^{43}$ We regard this adaptation as customary law because it is forced by radical

39 The following example is inspired and borrowed from Diala $2017 \mathrm{~J}$ of Legal Pluralism and Unofficial Law 153.

40 Bhe and Others $v$ Magistrate Khayelitsha and Others; Shibi $v$ Sithole; SAHRC $v$ President RSA 20051 BCLR 1 (CC).

41 Newman Women of the world: Sub-Saharan Africa (1984) 110.

42 Uchendu The Igbo of Southeast Nigeria (1965) 50.

43 Himonga Family and succession laws in Zambia: developments since independence (1995) 16-32; Diala "The shadow of legal pluralism in matrimonial property division outside the courts in Southern Nigeria” 2018 AHRLJ 706-731. 
socioeconomic changes, of which bills of rights and children's laws are prominent.

Other examples of indigenous laws transmuting to customary laws abound in land registration, ${ }^{44}$ adoption of children by women, ${ }^{45}$ succession to traditional leadership, ${ }^{46}$ disposal of parental consent in marriage, ${ }^{47}$ and monetisation of bride wealth payment. ${ }^{48}$ We proceed to a brief distinction between indigenous laws and customary laws.

\section{What is customary about African customary law?}

This is an interesting question; one which scholars are yet to satisfactorily answer. Is African customary law 'customary' because it is an unchanged remnant of the precolonial past or because it is a label for describing all forms of non-state laws to which Africans attach a sense of obligation? The latter response is more persuasive, since there is no historical continuity in African customary laws. Sanders observed that "today's autonomic customary law is not the same as the customary law of the pre-colonial past." 49 In agreement, we argue that the 'customariness' of customary laws is traceable to two intertwined elements.

The first is an amplified sense of obligation to people's indigenous practices, while the second is the confluence of interests between African elites and the postcolonial state, which inherited its capitalist hegemony. Regarding the second element, the process-oriented character of indigenous laws proved to be a double-edged sword. On the one hand, it made indigenous laws very receptive to change. On the other hand, it made it easy for African elites to exploit indigenous laws' flexibility to present distorted versions of customs to European authorities. Since the imperial and pecuniary interests of these two parties were incompatible with the dynamism of indigenous norms, they were compelled to give these norms rule-based features. ${ }^{50}$ Accordingly, they replaced the sense of obligation that guided indigenous laws with a sense of coercion. Along with acceptance, the sense of obligation became displaced with fear - the fear of the white man's courts and soldiers. ${ }^{51}$

44 Nwauche "Legal pluralism and access to land in Nigeria" in Mostert \& Bennett (eds) Pluralism and development: Studies in access to property in Africa (2012) 70 .

$45 K v M$ and Others (671/2013) 2014 ZALMPHC 5.

46 Shilubana and Others v Nwamitwa 20089 BCLR 914 (CC); 20092 SA 66 (CC).

47 Section 3(a) of the Recognition of Customary Marriages Act 1998.

48 Grosz-Ngaté "Monetization of bridewealth and the abandonment of "kin roads" to marriage in Sana, Mali” 1988 American Ethnologist 501-514.

49 Sanders "How customary is African customary law" 1987 Comparative and International LJ of SA 409.

50 For analysis of the political economy of customary law in post colonies, see Ghai, Luckham \& Snyder The political economy of law: A third world reader (1985) 1.

51 Spiers "The use of the Dum Dum bullet in colonial warfare" $1975 \mathrm{~J}$ of Imperial and Commonwealth History 3-14. 
To legitimise this new element of coercion, indigenous laws were endowed with historical antiquity, ${ }^{52}$ shrouded with a preservationist shadow, and brought under the suffocating shade of sanctions, whose alien nature is evidenced by the rarity of prisons in precolonial Africa. ${ }^{53}$ An example of the artificial antiquity of indigenous law is the Nigerian Evidence Act and customary court laws, which invariably define customary law as "a rule or body of customary rules ... fortified by established usage." Ultimately, rule-obsession or legal positivism invaded indigenous laws, muted their propensity to change, obscured their foundational values, and championed their "customariness." We know how this was done throughout the continent: customs were codified, trapped in judicial precedents, and interpreted in the courts with European lens of legal certainty. So, to return to the question: what is customary about African customary law?

The answer is practically nothing. Almost all aspects of customary laws are different from their precolonial forms and usages. As Snyder summed it, "the foundations of customary law in Africa lie partly in the development of capitalism and its expansion from Europe during the colonial era." 54 In ending our distinction of indigenous laws from customary laws, one thing must be stressed. Law - of whatever type - is not immutable. Precolonial indigenous laws would have changed with or without the influence of colonial rule. ${ }^{55}$ Our argument is that colonial rule hastened the pace of change in a manner so revolutionary that many precolonial norms lost their indigenous flavour. The comprehensive socioeconomic changes that occurred in African social fields in the areas of religion, education, commerce, leisure, and means of livelihoods, among others, disrupted the natural pace of normative changes. The consequences are so pervasive that they qualify as imposed changes. In this sense, state laws are the most powerful socioeconomic changes, constitutions are the poster pages of state laws, while customary laws are products of these changes. In what follows, we analyse the extent to which African constitutions recognise customary laws, thereby setting the stage for rethinking the interface between indigenous laws and constitutionalism.

\section{Constitutional recognition of customary law}

As shown in section II, socioeconomic changes underlie the intersection of historical discontinuities in indigenous African laws. The most visible

52 During fieldwork in Somaliland and Nigeria, it was common for informants to invoke the tradition of their ancestors to explain women's subordination in customs of male primogeniture and matrimonial property rights.

53 Novak "Capital punishment in precolonial Africa: The authenticity challenge" 2018 J of Legal Pluralism and Unofficial Law 76; Lewin "Crime and punishment in Africa" 1940 Howard J of Criminal Justice 245-247.

54 Snyder "Customary law and the economy" 1984 Journal of African Law 34.

55 Obiora "Reconsidering African customary law" 1993 Legal Studies Forum 217-252. 
aspects of these changes concern gender equality, dignity, succession, and property rights. They are very visible because they radically altered the close-knit structure of precolonial society, thereby changing people's attitudes and hastening the transformation of indigenous laws to customary laws. Specifically, the transformed aspects of indigenous laws concern group/family production of wealth, emphasis on communal interests over individualism, the basic nature of property, the processoriented character of norms, and the reconciliatory nature of dispute resolution. Accordingly, this section analyses the ways in which African constitutions acknowledge the transformation of indigenous laws to customary laws. These acknowledgements are the ways constitutions define customary law, mandate courts to apply customary law, and affirm socioeconomic changes that affect traditional society and drive the dynamism of customary law. We also examine provisions on the right to culture, communal life, equality of women and men, and matrimonial property, since these provisions reveal colonial-induced discontinuities in indigenous African laws.

Of the 26 constitutions surveyed, we highlight 13 only because they are on extreme ends of customary law recognition. In no order, these are South Africa, Nigeria, Cameroon, Gabon, Ghana, Kenya, Uganda, Tanzania, Rwanda, Zambia, Zimbabwe, and Mozambique. Our analysis is arranged thematically.

\section{Culture, traditional institutions, and communal life}

As the preceding discussion shows, communal life and traditional institutions in contemporary Africa are vastly different from what they were in precolonial times. Constitutions should help people to cope with radical changes in social life, specifically the dissonance between modernity and customs with agrarian origins. They can do this by affirming people's right to culture and traditional institutions, and subjecting these rights to human dignity and non-discrimination. By so doing, people's adaptations of indigenous laws to socioeconomic changes will find support in the highest law of the land. In this context, Kenya, South Africa, Uganda, Mozambique, and Zimbabwe have the most prominent provisions on the right to indigenous culture and communal life. We offer snippets of these provisions below.

The Kenya Constitution of 2010 establishes a National Land Commission to encourage the application of traditional dispute resolution mechanisms in land conflicts. Article 11(1) "recognises culture as the foundation of the nation and as the cumulative civilization of the Kenyan people and nation." Furthermore, article 56 mandates the state to take "affirmative action programmes designed to ensure that minorities and marginalised groups develop their cultural values, languages and practices." Article 159(2)(c) makes unparalleled provisions for "courts and tribunals [to] be guided by principles of alternative forms of dispute resolution, including reconciliation, mediation, arbitration and traditional dispute resolution mechanisms." In marked departure from 
colonial era land laws, article 63 guarantees that "community land shall vest in and be held by communities identified on the basis of ethnicity, culture or similar community of interest."

In a similar manner as Kenya, Mozambique strongly supports indigenous institutions. For example, article 118 of its Constitution provides: "The State shall recognise and esteem traditional authority that is legitimate according to the people and to customary law ... The State shall define the relationship between traditional authority and other institutions and the part that traditional authority should play in the economic, social and cultural affairs of the country ..." 56 This requirement to "define the relationship between traditional authority and other institutions" is a rare effort to legislatively clarify legal pluralism in Mozambique. Only South Africa comes close in clarifying legal pluralism by mandating the courts to "apply customary law when that law is applicable, subject to the Constitution and any legislation that specifically deals with customary law." 57 As we show below, this clarification is useful for asserting gender-related rights, as it enables women to confront the patriarchal reinforcements that accompanied the transformation of indigenous laws into customary law.

\section{Gender equality}

South Africa, Zambia, Zimbabwe, and Mozambique have firm customary law-related gender provisions. Indeed, South Africa, Zambia, and Zimbabwe went as far as establishing gender equality commissions. Intended or not, the manner these states emphasise the equality of spouses recognises how group production of wealth and women's independent income have diminished and increased respectively. For example, section 26 of the Zimbabwean Constitution of 2013 mandates the state to "take appropriate measures to ensure that (c) there is equality of rights and obligations of spouses during marriage and at its dissolution." Article 122 of the Constitution of Mozambique requires the state to "promote, support and value the development of women, and [to] encourage their growing role in society, in all spheres of political, economic, social and cultural life of the country."

Other states like Kenya, Ghana, and Uganda also protect gender equality in varying degrees. ${ }^{58}$ The Ghanaian Constitution of 1992 not only ensures women's right to property, it is also the only surveyed constitution that unequivocally affirms joint matrimonial property. Notably, section 22(3)(a) and (b) provides that "spouses shall have equal access to property jointly acquired during marriage," and "assets, which are jointly acquired during marriage shall be distributed equitably

56 Constitution of the Republic of Mozambique of 200434.

57 See s 211 (3) of the Constitution of South Africa Act 108 of 1996. To a lesser extent, Kenya and Uganda also attempt to clarify their legal pluralism.

58 See article 27 of the Kenyan Constitution of 2010 and art 32 (2) of the Ugandan Constitution of 1995, which recognises that women are a marginalised group in need of protection. 
between the spouses upon dissolution of the marriage." This remarkable recognition may be due to the matrilineal nature of some Ghanaian societies.

\section{Dynamism of indigenous law}

African states do not seem to grasp fully the hardships that result from applying indigenous norms in industrial conditions different from the agrarian settings in which these norms emerged. Dissonance between the origins of indigenous norms and their application in modern conditions invokes the dynamism of indigenous law - that is its ability to respond to the hardships which women suffer in inheritance and matrimonial property issues. As shown above, only Ghana, Kenya, South Africa, Zambia, Zimbabwe, and to a lesser extent, Uganda, strongly affirm gender equality within the context of this dynamism. ${ }^{59}$ Of these states, Ghana stands head and shoulders above the others, since it seems particularly conscious of women's loss of their economic powerhouse status following the industrialisation and land appropriation policies of British colonialism. For example, section 36(6)(7) of the Ghanaian Constitution mandates the state to "take all necessary steps ... to ensure the full integration of women into the mainstream of the economic development of Ghana" and "guarantee" their ownership of property and right of inheritance. ${ }^{60}$ Section 39 mandates the state to adapt "customary and cultural values" to "the growing needs of the society," while section 270 grants traditional institutions a role in customary law's development.

South Africa prefers to tackle the dynamism of indigenous laws through the courts. Section 39(2) of its constitution provides that "when interpreting any legislation, and when developing the common law or customary law, every court, tribunal, or forum must promote the spirit, purport and objects of the Bill of Rights." Zambia and Zimbabwe give this promotion function to chiefs. Their role in Zambia is, among others, to "initiate, discuss and make recommendations to the National Assembly regarding socio-economic development" and "advise the Government on traditional and customary matters." 61 In Zimbabwe, their role includes the preservation of culture, facilitation of development, and resolution of "disputes amongst people in their communities in accordance with customary law."62

From the surveys, there is increasing recognition of customary law in constitutions adopted in the last twenty years. Also, recent constitutions, including constitutional amendments, seem to emulate the Constitution of South Africa. For example, Kenya and Zimbabwe heavily copied the

59 S 33 of the Constitution of Uganda of 1995 has elaborate provisions for protecting the rights of women.

60 See also s 27(3) and s 36(6).

61 See art 165 and art 169 of the Zambian Constitution of 2016.

62 S 282 of the Zimbabwean Constitution of 2013. 
duty imposed on the courts to interpret indigenous law in accordance with the Bill of Rights.

Conversely, the constitutions of Cameroon, Gabon, Nigeria, Rwanda, and Tanzania have the least recognition of customary law. They do not define its relationship with state laws, contain no matrimonial property rights, and have insignificant or no provisions on the right to culture, traditional institutions, and the status of chiefs, monarchs, and elders. Although article 201 of the Rwandan Constitution of 2003 appears to recognise that indigenous law transforms to customary law, it paints a condescending image of this transformation. It states: "Unwritten customary law remains applicable as long as it has not been replaced by written laws, is not inconsistent with the Constitution, laws and regulations, and does not violate human rights, prejudice public order or offend public decency and morals." Article 201's emphasis on orality demonstrates the influence of codification on the transformation of indigenous laws into customary law. Codification brings coercion, legal certainty, and judicial precedents. Unfortunately, these features of imperial law are incompatible with the dynamism of indigenous laws. As we show shortly, they make it difficult for people to assert changing social conditions.

\section{Implications of customary law's status}

The inferior constitutional status of customary law has negative impacts on justice delivery, especially regarding the rights of marginalised groups such as women, female children, and younger males. We demonstrate this argument with matrimonial property rights under customary law. As stated, women's marital property rights in the precolonial era flowed from the close-knit nature of social life, in which family income was jointly derived from farming, hunting, and fishing. This is no longer the case. For a start, the nature of family property has changed from huts, sleeping mats, farm implements, and fishing nets to sophisticated cars, refrigerators, televisions, and modern buildings. Similarly, the communal structure of the extended family is giving way to migrant labour and nuclear families with individualistic mannerisms. Furthermore, income is now earned independently, with women contributing directly to the acquisition of new forms of property. With this type of changed social settings, it is inhumane to continue with the indigenous law of matrimonial property, which subsumes a married woman's property rights in her husband. ${ }^{63}$ In the absence of a supportive legislative framework, divorcing women's only recourse is judicial creativity or activism. However, given the disproportionate gender balance in African judiciaries and the legal positivist training of judges, litigation does not offer much hope for meeting the justice needs

63 For discussion, see Moore \& Himonga “Protection of women's marital property rights at the end of a customary marriage: A view from inside and outside the courts" (2015) CSSR Working Paper 350; Diala 2018 AHRLJ 706731. 
of divorcing women. This is where the constitution's role becomes crucial.

\section{Concluding proposals}

We propose that African constitutions should spearhead the integration of customary law with state law by adopting the foundational values of indigenous laws as constitutional principles. These easily ascertainable values include humaneness, family continuity, ${ }^{64}$ preservation of the ancestral home, ${ }^{65}$ the duty of care owed to family members by the family head, ${ }^{66}$ and the non-individual nature of marriage. ${ }^{67}$ Changewise, South Africa's Constitutional Court has noted that the foundational values of indigenous laws are more stable than indigenous laws because they motivate the ways people adapt their behaviour to socioeconomic changes. ${ }^{68}$ Our proposal presents these foundational values as a basis for the evolution of a common law in African countries. ${ }^{69}$ As far back as 1960 , Allot observed that "customary laws in modern Africa are growing more alike." 70 His observation mirrors our argument that the colonial experience created contemporary customary law by forcing people to adapt indigenous laws to socioeconomic changes. We have already given codifications, restatements, judicial precedents, and repugnancy clauses as examples of how customary law was created. Indeed, the modus of this creation reflects experiences in territories that experienced Roman law. In these places, the common law tradition itself is the product of " $a$ dynamic and essentially customary system."71 For example, legal integration founded on customary law was successfully implemented in Pacific Island nations such as Papua New Guinea, Solomon Islands,

64 Van Niekerk "Succession, living indigenous law and Ubuntu in the Constitutional Court" 2005 Obiter 474-487.

65 Fombad "Gender equality in African customary law: Has the male Ultimogeniture rule any future in Botswana?" $2014 \mathrm{~J}$ of Modern African Studies 478.

66 Mbatha 2002 SAJHR 259-286.

67 Radcliffe-Brown \& Forde African Systems of Kinship and Marriage (1950) 1.

68 Cousins "Contextualising the controversies: dilemmas of communal tenure reform in post-apartheid South Africa" in Land, power \& custom: controversies generated by South Africa's Communal Land Rights Act (ed Claassens \& Cousins) (2008) 25.

69 For a somewhat similar idea, see Ndima "The resurrection of the indigenous values system in post-apartheid African law: South Africa's constitutional and legislative framework revisited" 2014 SAPL 311 [urging "for the development of a sound theory of African law's re-indigenisation which would anchor the system firmly to both African values and the Bill of Rights as envisioned by the Constitution"].

70 Allott Essays in African law: With special reference to the law of Ghana (1960) 63.

71 Aleck "Beyond recognition: contemporary jurisprudence in the Pacific islands and the common law tradition" 1991 Queensland University of Technology LJ 141-143. 
Vanuatu, and Western Samoa. ${ }^{72}$ Following their independence, these nations placed customary law on a higher or equivalent status with the imposed colonial law by making it their primary source of law. ${ }^{73}$ Their efforts reflected their desire to move their legal systems away from the imposed common law tradition and establish it on "the customs, values and traditions of the people."74 As a commentator explained it, the ultimate goal was "to bring about the development of "a new, culturally sensitive ... jurisprudence which blend[s] customary law and institutions with modern Western law and institutions in an appropriate mix."75 In this context, it makes sense to use the foundational values of indigenous laws as constitutional principles. ${ }^{76}$ After all, scholars such as Fuller and Webber asserted that "all law is customary", or at the very least, the primary form of law was customary. ${ }^{77}$

In conclusion, it is probably impossible to exhaust the impact of coloniality on African indigenous laws. As Fitzpatrick stated, "existing social relations were taken, reconstituted in terms of its imperatives and then, as it were, given back to the people as their own. In this, history was denied, and tradition created instead."78 Since Africans cannot turn back the hands of their legal clock, they may as well embrace change in a manner that achieves justice for marginalised groups.

72 See, for example, Weisbrot "The post-independence development of Papua New Guinea's legal institutions" 1987 Melanesian LJ 45-46; Powles "The common law as a source of law in the South Pacific: experiences in Western Polynesia" 1988 University of Hawaii LR 105.

73 See, for example, the Underlying Law Act 13 of 2000 of Papua New Guinea, the Laws of Kiribati Act of 1989, the Laws of Tuvalu Act of 1987, and the Customs and Adopted Laws Act 1971 of Nauru.

74 Goldring The Constitution of Papua New Guinea (1978) 150.

75 Aleck 1991 Queensland University of Technology LJ 139, citing Weisbrot 1988 Melanesian LJ 2.

76 These principles can start their journey from constitutional preambles and work themselves into bills of rights.

77 Fuller "Human interaction and the law" 1969 American Journal of Jurisprudence; Webber "The grammar of customary law" 2009 McGill Law Journal 579-582.

78 Fitzpatrick "Is it simple to be a Marxist in legal anthropology?" 1985 Modern Law Review 479. 